\title{
Different Factors Affect Developmental Competence and Cryotolerance in in vitro Produced Bovine Embryo
}

\author{
Kei IMAI ${ }^{1)}$, Satoko MATOBA ${ }^{2)}$, Osamu DOCHI ${ }^{3)}$ and Itsuo SHIMOHIRA ${ }^{2)}$ \\ ${ }^{1)}$ Laboratory of Reproductive Biology and Technology, National Institute of Agrobiological Sciences, Kukizaki, Ibaraki 305-8602, \\ ${ }^{2)}$ Department of Technology, National Livestock Breeding Center, Nishigo, Fukushima 961-8511 and ${ }^{3)}$ Department of Dairy Science, \\ Animal Reproduction, Rakuno Gakuen University, Ebetu, Hokkaido 069-8501, Japan
}

(Received 16 January 2002/Accepted 7 May 2002)

\begin{abstract}
The present study was conducted to examine the effects of culture systems and culture media on developmental competence and freezability of bovine embryos obtained by in vitro culture of in vitro matured and fertilized (IVM-IVF) oocytes. No significant difference was observed in the proportions of oocytes developed to blastocysts, the speed at which the oocytes reached the blastocyst stage and the number of cells, when the IVM-IVF oocytes were cultured in CR1aa with or without cumulus cells. Nevertheless, more of the IVM-IVF oocytes cultured either with or without cumulus cells in CR1aa were seen to reach the blastocyst stage much sooner than those cultured with cumulus cells in TCM199 $(\mathrm{P}<0.05)$. The proportion of embryos developed to the blastocyst stage by day 7 in CR1 aa culture was significantly higher than embryos cultured in TCM199. Viability after frozen-thawed blastocysts were obtained in vitro, was seen in a significantly higher percentage of embryos cultured in TCM199 and developed to the hatched blastocysts than in those cultured in CR1aa $(\mathrm{P}<0.05)$. These results indicate that CR1aa was superior to TCM199 for the potential developmental of IVMIVF oocytes to blastocysts during in vitro culture regardless of co-culture with or without cumulus cells. But the freezability of blastocysts developed in CR1aa was inferior to those developed in TCM199.

KEY WORDS: culture medium, developmental competence, freezability, in vitro culture, in vitro produced bovine embryo.
\end{abstract}

J. Vet. Med. Sci. 64(10): 887-891, 2002

In vitro culture of bovine embryos derived from IVMIVF have succeeded in producing calves $[10,21]$. An adequate in vitro culture system for bovine zygotes is required for large scale embryo production by IVM-IVF and genetic improvement by means of ovum pick-up and IVM-IVF. This culture system is used for the development and efficient utilization of embryonic techniques in cattle, for example for embryonic or somatic cell nuclear transfer and in transgenic animals. Bovine IVM-IVF zygotes were first cultured with cumulus cells $[8,10]$, oviduct epithelial cells $[9,21]$, granulosa cells [13], amnion cells [2] and buffalo rat liver cells [36] in TCM199 supplemented with bovine serum, but there are many differences between in vitro produced bovine embryos and those produced in vivo. It was reported that in vitro produced embryos have darker cytoplasm and lower density [24, 25]. CR1aa medium was developed for in vitro culture of bovine IVM-IVF zygotes $[15,29,30]$, but the optimum culture system for IVM-IVF oocytes and freezability of blastocysts cultured in CR1aa still remain to be clarified. The chilling sensitivity should be considered as a factor affecting the quality of in vitro produced bovine blastocysts.

The aim of the present study was to examine the effects of culture systems and culture media on the development competence and the quality of bovine embryos obtained by in vitro culture of IVM-IVF oocytes.

\section{MATERIALS AND METHODS}

Collection of oocytes and in vitro maturation: Bovine ovaries were obtained within $30 \mathrm{~min}$ after slaughter in a local slaughterhouse, immersed in physiological saline solution at $25^{\circ} \mathrm{C}$ and transported to the laboratory. Small follicles ( 2 to $6 \mathrm{~mm}$ in diameter) on the surface of the ovaries were punctured and aspirated with a 19-gauge hypodermic needle connected to a $5 \mathrm{~m} l$ syringe. Only oocytes with compact cumulus cells were selected, washed once with PB1 supplemented with $3 \%$ calf serum (CS; calf serum, GIBCO BRL, Gland Island, NY, U.S.A.), and then washed twice with 25 mM Hepes buffered TCM199 (Medium199, GIBCO BRL) supplemented with 5\% CS (maturation medium). Oocytes (50 to 80 ) were cultured for $20 \mathrm{hr}$ in a droplet of $600 \mu \mathrm{l}$ maturation medium covered with mineral oil (E. R. Squibb \& Sons, Inc., Princeton, NJ, U.S.A.) at $38.5^{\circ} \mathrm{C}$ at $99 \%$ relative humidity and in $2 \% \mathrm{CO}_{2}$ in air. Each medium contained $100 \mathrm{IU} / \mathrm{m} l$ penicillin $\mathrm{G}$ potassium (Meiji Seika Co., Tokyo, Japan) and $100 \mu \mathrm{g} / \mathrm{m} l$ streptomycin sulfate (Meiji Seika Co., Tokyo, Japan).

Sperm preparation and in vitro fertilization: Throughout the present study, semen was collected from only one Japanese Black bull. Spermatozoa were treated as described by Niwa and Ohgota [23]. Briefly, $0.5 \mathrm{~m} l$ straws were thawed in a water bath at $37^{\circ} \mathrm{C}$ and washed twice with $6 \mathrm{~m} l$ of BO medium (Brackett and Oliphant medium without glucose and bovine serum albumin) supplemented with $10 \mathrm{mM}$ caffeine (caffeine sodium benzoate, Sigma Chemical, St. Louis, MO, U.S.A.) and $4 \mathrm{IU} / \mathrm{m} l$ heparin (Novo heparin, Kodama Chemical, Tokyo, Japan) by centrifugation (at 500 $\mathrm{g}$ for $5 \mathrm{~min}$ ). After washing, the concentration of spermatozoa was adjusted to $12.5 \times 10^{6}$ spermatozoa $/ \mathrm{m} l$ in the BO medium. The final concentration of sperm suspension was then adjusted to $6.25 \times 10^{6}$ spermatozoa $/ \mathrm{ml}, 5 \mathrm{mM}$ caffeine, 
$2 \mathrm{IU} / \mathrm{m} l$ heparin and $10 \mathrm{mg} / \mathrm{m} l$ BSA by adding the same volume of BO medium containing $20 \mathrm{mg} / \mathrm{m} l$ bovine serum albumin (BSA, crystallized and lyophilized, Sigma Chemical, St. Louis, MO, U.S.A.) without glucose, heparin or caffeine. Droplets with a volume of $100 \mu l$ of the sperm suspension covered with mineral oil were prepared, and about 20 in vitro matured oocytes were transferred to each droplet, then incubated for $5 \mathrm{~h}$ at $38.5^{\circ} \mathrm{C}, 2 \% \mathrm{CO}_{2}$ in air. The oocytes subjected to insemination were used in the following three experiments.

Experiment 1: The aim of Experiment 1 was to examine by three distinct culture methods the developmental competence of bovine embryos obtained by in vitro culture of IVM-IVF oocytes. After insemination, cumulus cells were removed in a modified CR1 aa [18] supplemented with 5\% $\mathrm{CS}$ by pipetting. Oocytes were allocated to the following three groups: oocytes which were cultured without cumulus cells in the modified CR1aa supplemented with 5\% CS (Group 1), oocytes which were co-cultured with cumulus cells in the modified CR1aa supplemented with 5\% CS (Group 2), and oocytes which were co-cultured with cumulus cells in TCM199 supplemented with 5\% CS (Group 3) as a control. Oocytes suspended in Group 1 or Group 2 were cultured under a gas phase of $5 \% \mathrm{CO}_{2}$ in air with saturated humidity at $38.5^{\circ} \mathrm{C}$. Oocytes suspended in Group 3 were cultured under a gas phase of $2 \% \mathrm{CO}_{2}$ in air with saturated humidity at $38.5^{\circ} \mathrm{C}$ in order to get a higher incidence of blastocyst [7]. In every group, 50 to 80 oocytes were placed in a $600 \mu \mathrm{l}$ of droplet of in vitro culture medium under mineral oil. At $48 \mathrm{hr}$ after insemination, the oocytes were examined for cleavage and development. On Days 7 to 9 after insemination, the rates of blastocysts were calculated.

Experiment 2: The aim of Experiment 2 was to calculate the number of cells in blastocysts derived from each group in Experiment 1. First, at 7 days after insemination, embryos were classified with respect to their developmental stage, late morulae, early blastocyst, blastocyst and expanded blastocyst. Second, the numbers of nuclei of embryos from each group were counted under a fluorescence microscope after they were dyed with hoechst 33342. Briefly, the zona pellucida was removed by using a $1 \%(\mathrm{w} /$ v) pronase solution. Denuded embryos were mounted with 2 to $3 \mu l$ of pronase solution on a slide glass, and $15 \mu l$ of hoechst 33342 was mixed with a droplet containing the denuded embryo on a slide glass, followed by mounting with a cover glass. The number of nuclei was taken as the number of cells.

Experiment 3: The aim of Experiment 3 was to examine the effect of freezing and thawing on survival of embryos which developed into blastocysts and further stages by Days 7 or 8 in Experiment 1. Embryos were equilibrated with 1.5 $\mathrm{M}$ ethylene glycol (EG) in PB1 supplemented with $20 \%$ fetal calf serum (FCS) for $15 \mathrm{~min}$ at room temperature followed by loading into a $0.25 \mathrm{~m} l$ plastic straw. The straw containing embryos was plunged into $\mathrm{a}-7^{\circ} \mathrm{C}$ ethanol bath of a programmable freezer (ET-UM, Fujiya Yano Science, Sapporo, Japan), seeded at $-7^{\circ} \mathrm{C}$, cooled to $-30^{\circ} \mathrm{C}$ at the rate of $-0.3^{\circ} \mathrm{C} / \mathrm{min}$ after $8 \mathrm{~min}$ of holding at $-7^{\circ} \mathrm{C}$, and then plunged into liquid nitrogen [4]. The frozen straws were stored in liquid nitrogen for more than $24 \mathrm{hr}$ and thawed by immersion in air for $10 \mathrm{sec}$ and in water at $30^{\circ} \mathrm{C}$ for 10 to 20 sec. Ethylene glycol was removed from the embryos by 10 min-immersion in PB1 supplemented with $20 \%$ FCS warmed at $38.5^{\circ} \mathrm{C}$. The embryos were cultured in $100 \mu \mathrm{l}$ droplets of TCM199 supplemented with $20 \%$ FCS and 0.1 $\mathrm{mM} \beta$-mercaptoethanol (TCM199- $\beta \mathrm{ME}$ ) after washing them with PB1 supplemented with $20 \%$ FCS (twice) and with the medium (once), under a gas phase of $5 \% \mathrm{CO}_{2}$ in air at $38.5^{\circ} \mathrm{C}$ [32]. The blastocysts, which were developed by the same culture method as Group 1, were cultured in TCM199- $\beta$ ME without freezing and thawing as a control. The criteria of embryo viability were defined as the number of embryos in which the blastocoele had re-expanded and its maintenance within $24 \mathrm{hr}$ of culture, the number that had developed to the hatching blastocyst within $48 \mathrm{hr}$ and the number that had developed to the hatched blastocyst within $96 \mathrm{hr}$.

Statistical analyses: Development and viability of embryos were analyzed by the chi-square test and ANOVA for arc sine transformed proportions. The numbers of cells in embryos were analyzed by Student's $t$-test.

\section{RESULTS}

Experiment 1: Table 1 shows the results of comparison of three distinct culture methods in relation to the cleavage rate

Table 1. Effects of culture methods in IVM-IVF oocytes at the one-cell stage developing to the blastocyst stage

\begin{tabular}{|c|c|c|c|c|c|c|}
\hline $\begin{array}{l}\text { Culture } \\
\text { methods }\end{array}$ & $\begin{array}{c}\text { No. of } \\
\text { oocytes } \\
\text { inseminated }(*)\end{array}$ & $\begin{array}{c}\% \pm \mathrm{SD} \text { of } \\
\text { cleaved embryos } \\
\text { on Day } 2\end{array}$ & $\begin{array}{c}\% \pm \mathrm{SD} \text { of } \\
\text { blastocysts on } \\
\text { Day } 7 \text { to } 9\end{array}$ & $\begin{array}{c}\% \pm \text { SD of } \\
\text { blastocysts on } \\
\text { Day } 7 * *\end{array}$ & $\begin{array}{c}\% \pm \mathrm{SD} \text { of } \\
\text { blastocysts on } \\
\text { Day } 8^{* *}\end{array}$ & $\begin{array}{c}\% \pm \mathrm{SD} \text { of } \\
\text { blastocysts on } \\
\text { Day } 9 * *\end{array}$ \\
\hline Group 1 & $379(5)$ & $80.0 \pm 8.4$ & $49.1 \pm 7.1(186)^{\mathrm{e})}$ & $56.4 \pm 15.1(106)^{\mathrm{a})}$ & $31.4 \pm 11.4(58)^{\mathrm{c})}$ & $12.1 \pm 5.9(22)$ \\
\hline Group 2 & $397(5)$ & $76.1 \pm 6.5$ & $46.4 \pm 3.8(184)^{\mathrm{e})}$ & $62.2 \pm 10.7(114)^{a)}$ & $29.6 \pm 10.2(55)^{\mathrm{c})}$ & $8.2 \pm 3.9(15)$ \\
\hline Group 3 & $397(5)$ & $80.5 \pm 8.9$ & $38.8 \pm 5.5(154) f)$ & $36.4 \pm 9.3(56)^{\mathrm{b})}$ & $48.4 \pm 8.0(74)^{d)}$ & $15.1 \pm 5.5(24)$ \\
\hline
\end{tabular}

Group 1: Zygotes cultured without cumulus cells in modified CR1aa supplemented with 5\% CS.

Group 2: Zygotes cultured with cumulus cells in modified CR1aa supplemented with 5\% CS.

Group 3: Zygotes cultured with cumulus cells in TCM199 supplemented with 5\% CS.

$\mathrm{a}-\mathrm{b}), \mathrm{c}-\mathrm{d})$ and $\mathrm{e}-\mathrm{f})$ Values with different superscripts are significantly different $(\mathrm{P}<0.05)$.

* Number of replicates for experiments.

** Data are based on the total number of blastocysts during Days 7 to 9 (Day $0=$ day of insemination). 
Table 2. Developmental stage of embryos cultured for 7 days after insemination

\begin{tabular}{lccccc}
\hline $\begin{array}{l}\text { Culture } \\
\text { methods }\end{array}$ & $\begin{array}{c}\text { No. of } \\
\text { oocytes } \\
\text { inseminated (*) }\end{array}$ & $\begin{array}{c}\text { No. of } \\
\text { expanded } \\
\text { blastocysts (\%) }\end{array}$ & $\begin{array}{c}\text { No. of } \\
\text { blastocysts (\%) }\end{array}$ & $\begin{array}{c}\text { No. of } \\
\text { early } \\
\text { blastocysts (\%) }\end{array}$ & $\begin{array}{c}\text { No. of } \\
\text { compact } \\
\text { morulae (\%) }\end{array}$ \\
\hline Group 1 & $388(5)$ & $64(16)^{\mathrm{a})}$ & $44(11)$ & $27(7)$ & $15(4)$ \\
Group 2 & $397(5)$ & $70(18)^{\mathrm{a})}$ & $48(12)$ & $37(9)$ & $7(2)$ \\
Group 3 & $405(5)$ & $32(8)^{\mathrm{b})}$ & $29(7)$ & $40(10)$ & $31(8)$ \\
\hline
\end{tabular}

a-b) Values with different superscripts are significantly different $(\mathrm{P}<0.05)$.

* Number of replicates for experiments.

Table 3. Numbers of cells in embryos in individual developmental at stage 7 days after insemination

\begin{tabular}{cccc}
\hline Developmental & \multicolumn{2}{c}{ No. of cells (no. examined) in embryos cultured in* } \\
\cline { 2 - 4 } stage & Group 1 & Group 2 & Group 3 \\
\hline Expanded blastocyst & $139 \pm 36(62)^{* *}$ & $140 \pm 32(70)$ & $141 \pm 42(32)$ \\
Blastocyst & $103 \pm 29(44)^{\mathrm{a}, \mathrm{b})}$ & $116 \pm 43(48)^{\mathrm{a})}$ & $98 \pm 28(29)^{\mathrm{b})}$ \\
Early blastocyst & $74 \pm 31(27)$ & $70 \pm 30(33)^{* *}$ & $81 \pm 36(41)$ \\
Compact morula & $82 \pm 36(15)$ & $79 \pm 52(7)$ & $72 \pm 27(30)^{* *}$ \\
\hline Total & $111 \pm 42(148)^{\mathrm{c})}$ & $116 \pm 46(158)^{\mathrm{c})}$ & $97 \pm 43(132)^{\mathrm{d})}$ \\
\hline
\end{tabular}

$a-b), c-d)$ Values with different superscripts are significantly different $(\mathrm{P}<0.05)$.

$*$ Mean \pm SD

** Two, 4 and 1 embryo missed in analyzing in Groups 1, 2 and 3, respectively.

and rate of development to blastocysts. No significant difference was observed among the three culture systems as to cleavage rates $(76 \%$ to $81 \%)$. Rates of development to the blastocyst stage in Group 1 (49\%) and Group 2 (46\%) were significantly higher than that in Group $3(39 \% ; \mathrm{P}<0.05)$. More than half developed to the blastocyst stage by Day 7 in Groups 1 and 2, but in Group 3 the highest proportion was found on Day 8 . There were significant differences between the CR1 group (Group $1(56 \%)$, Group $2(62 \%)$ ) and the control (Group $3(36 \%))(\mathrm{P}<0.05)$. On the other hand, the proportions of blastocysts developed on Day 8 in Group 1 $(31 \%)$ and Group $2(30 \%)$ were lower than that in Group 3 $(48 \% ; \mathrm{P}<0.05)$.

Experiment 2: The numbers of cells which developed to compact morulae, early blastocysts, blastocysts and expanded blastocysts were counted. The proportions of embryo development are shown in Table 2. The proportions of embryos which developed to the blastocyst stage and onwards in Groups 1,2 and 3 showed the same trend as in experiment 1 (Tables 1,2 ). As a result, only 150/388, 162/ 397 and 133/405 embryos were subjected to cell number analysis in groups 1,2 and 3. The mean numbers of cells ( \pm standard deviation (SD)) in embryo at each stage of development on Day 7 after fertilization are showed in Table 3. No significant difference was found in each developmental stage among Groups 1, 2 and 3, except for a difference between Groups 2 and 3 in the blastocyst stage $(\mathrm{P}<0.05)$. But the average numbers of cells in embryos cultured in Group 1 or Group 2 was greater than in embryos cultured in Group 3 in all developmental stages $(\mathrm{P}<0.01)$.

Experiment 3: The viabilities of frozen and thawed blas- tocysts after $96 \mathrm{hr}$ in culture in Groups 1, 2 and 3 were 36\% (35/96), 35\% (34/98) and 57\% (41/72), respectively (Table 4). The viabilities of Group 1 and Group 2 were significantly lower than that of Group $3(\mathrm{P}<0.05)$. In Experiment 3 , the embryos, which developed to blastocysts in Group 1 (47\%), Group 2 (47\%) and Group 3 (39\%), were used. The number of Day 7/Day 8 (ratio of Day 7) blastocysts for use to experiment 3 in Groups 1, 2 and 3 were 56/40 (58), 59/39 (60) and 30/42 (42), respectively. The Day 7 blastocysts ratios in Groups 1 and 2 were higher than that in Group 3 $(\mathrm{P}<0.05)$.

\section{DISCUSSION}

In the present study, CR1aa as the basal medium (Group 1 and Group 2) stimulated embryo development, and significantly higher incidence and faster development to the blastocyst stage was found than in those cultured in Group 3 (Tables 1 and 2), but there were no significant differences in the numbers of cells among Groups 1, 2 and 3, except for between blastocyst stage in Group 2 and Group $3(\mathrm{P}<0.05$, Table 3). When embryos were cultured in modified CR1aa, the numbers of cells was not affected either with nor without cumulus. As the number of cells was considered to be one of the qualitative indicators of embryo development $[5,12$, 20], cultures in Groups 1 and 2 are more appropriate than that in Group 3 for IVM-IVF embryos. The difference may be due to containing $5.56 \mathrm{mM}$ glucose in TCM199 and the difference between CR1 aa based media and TCM199 in the development rate and speed depending on the composition of the medium. It was necessary to co-culture with somatic 
Table 4. Viability of blastocysts after freezing and thawing

\begin{tabular}{lcccc}
\hline \multirow{2}{*}{$\begin{array}{c}\text { Culture } \\
\text { methods }\end{array}$} & $\begin{array}{c}\text { No. of } \\
\text { frozen-thawed } \\
\text { blastocysts }\end{array}$ & \multicolumn{2}{c}{ No. of blastocysts which maintained viability for (\%) } \\
\cline { 3 - 5 } & $24 \mathrm{hr}$ & $48 \mathrm{hr}$ & $96 \mathrm{hr}$ \\
\hline Group 1 & $96(3)^{*}$ & $56(58)^{\mathrm{b})}$ & $37(39)^{\mathrm{d})}$ & $35(36)^{\mathrm{f})}$ \\
Group 2 & $98(3)$ & $61(62)^{\mathrm{b})}$ & $34(35)^{\mathrm{d})}$ & $34(35)^{\mathrm{f}}$ \\
Group 3 & $72(3)$ & $59(82)^{\mathrm{a})}$ & $45(63)^{\mathrm{c})}$ & $41(57)^{\mathrm{e})}$ \\
\hline Control** & $31(3)$ & $31(100)$ & $29(94)^{*}$ & $30(97)^{-}$ \\
\hline
\end{tabular}

$a-b), c-d)$ and e-f) Values with different superscripts are significantly different $(\mathrm{P}<0.05)$. Only blastocysts, which developed on days 7 and 8 after fertilization, were used in Experiment 3.

* Number of replicates for experiments.

** The blastocysts which were developed by same culture method as Group 1, were cultured in TCM199 supplemented with $20 \%$ FCS and $0.1 \mathrm{mM} \beta$-mercaptoethanol without freezing and thawing.

cells when IVF zygotes developed to the blastocyst stage with TCM199 as the basal medium under a atmosphere of $5 \% \mathrm{CO}_{2}$ in air $(7,9)$. Co-culture with somatic cells affects embryo development-not only secretion of growth factors but also glucose reduction caused by their metabolism [7, 27]. Kim et al. [17] reported that supplementation TCM199 with $5.56 \mathrm{mM}$ glucose suppressed embryo development, and the same effect of glucose was reported in other culture media $[18,22,30,34]$. Therefore, it is considered that glucose as a component of TCM199 delays and reduces the development of embryos in vitro.

In the present study, the rate of developmental to blastocysts by Day 7 in Group $3(42 \%)$ was lower than that in Groups 1 and $2(58 \%, 60 \%)$. Nevertheless, the post-thaw viability of embryos cultured in either Group 1 or Group 2 was lower than that of embryos cultured in Group 3. This higher post-thaw viability of blastocysts from Group 3 may not result from the differences in development speed and the numbers of cells. Because, in in vitro culture, bovine blastocysts produced by Day 7 after insemination contained a greater number of cells and had better post-thaw viability than those of blastocysts on Day $8[5,31]$. The results of the present study agreed with previous reports which achieved better post-thaw viability in TCM199 [28]. There are several reports stating that there were changes in viability after freezing and thawing in embryos which were produced in vivo and in vitro $[16,19,33]$, co-cultured with different types of somatic cells $[14,36]$, cultured in medium supplemented with or without serum [26] and supplemented with ascorbic acid [35] or insulin-transfferin-selenium [33] in the culture medium. All previous reports suggested that embryos produced in vitro were more sensitive to low temperature and had poorer cryotolerance than those produced in vivo. There are two hypotheses: that the lipid concentration in embryonic cytoplasm increased during in vitro culture $[1,3,6]$ and lipid peroxidation occurred in the cell membrane during in vitro culture, freezing and thawing [11, 26]. Tarin and Trounson [35] reported that inhibition of lipid oxidation in lipids was responsible for embryo viability after freezing and thawing. Although TCM199, which was used in the present study, contains anti-oxidants such as ascorbic acid and $\alpha$-tocopherol, modified CR1aa does not originally contain any anti-oxidant. Consequently, embryos cultured in modified CR1aa in the present study might have had their cell membranes damaged during in vitro culture, freezing and thawing. The damage may induce irreversible hyperoxidation on the cell membrane, which consists of phospholipids.

In conclusion, compared with TCM199, modified CR1aa medium improved the rate of embryo development to the blastocyst stage in cultures for bovine IVM-IVF oocytes, but the post-thaw viability of embryos cultured in modified CR1aa medium was lower than that of embryos cultured in TCM199. Different factors are involved in the in vitro culture of IVM-IVF oocytes for the improvement of developmental competence and cryotolerance. Further study is needed to clarify factors affecting the freezability of in vitro produced bovine embryos.

ACKNOWLEDGMENTS. The authors are grateful to Dr. Toshiyuki Kojima and Dr. Kazuyoshi Hashizume for critical reading and editing of the manuscript.

\section{REFERENCES}

1. Abe, H., Yamashita, S., Itoh, T., Satoh, T. and Hoshi, H. 1999. Ultrastructure of bovine embryos developed from in vitromatured and -fertilized oocytes: comparative morphological evaluation of embryos cultured either in serum-free medium or in serum-supplemented medium. Mol. Reprod. Dev. 53: 325335.

2. Aoyagi, Y., Fukui, Y., Iwazumi, Y., Urakawa, M. and Ono, H. 1990. Effects of culture systems on development of in vitro fertilized bovine ova into blastocysts. Theriogenology 34: 749759.

3. Crosier, A.E., Farin, P.W., Dykstra, M.J., Alexander, J.E. and Farin, C.E. 2000. Ultrastructural morphometry of bovine compact morulae produced in vivo or in vitro. Biol. Reprod. 62: $1459-1465$.

4. Dochi, O., Imai, K. and Takakura, H. 1995. Birth of calves after direct transfer of thawed bovine embryos stored frozen in ethylene glycol. Anim. Reprod. Sci. 38: 179-185. 
5. Enright, B.P., Lonergan, P., Dinnyes, A., Fair, T., Ward, F.A., Yang, X. and Boland, M.P. 2000. Culture of in vitro produced bovine zygotes in vitro vs in vivo: implications for early embryo development and quality. Theriogenology 54: 659-73.

6. Fair, T., Lonergan, P., Dinnyes, A. Cottell, D.C., Hyttel, P. and Ward, F.A. 2001. Ultrastructure of bovine blastocysts following cryopreservation: effect of method of blastocyst production. Mol. Reprod. Dev. 58: 186-195.

7. Fukuda, Y. 1992. Development of early bovine embryos by coculture: Development to the blastocyst stage by coculture with cumulus cells. J. Reprod. Dev. 38: j157-j164 (in Japanese).

8. Fukuda, Y., Ichikawa, M., Naito, K. and Toyoda, Y. 1990. Birth of normal calves resulting from bovine oocytes matured, fertilized, and cultured with cumulus cells in vitro up to the blastocyst stage. Biol. Reprod. 42: 114-119.

9. Fukui, Y. and Ono, H. 1988. In vitro development to blastocyst of in vitro matured and fertilized bovine oocytes. Vet. Rec. 122: 282.

10. Goto, K., Kajihara, Y., Kosaka, S., Koba, M., Nakanishi, Y. and Ogawa, K. 1988. Pregnancies after co-culture of cumulus cells with bovine embryos derived from in-vitro fertilization of in-vitro matured follicular oocytes. J. Reprod. Fertil. 83: 753758.

11. Guyader-Joly, C., Ponchon, S., Durand, M., Heyman, Y., Renard, J.P. and Menezo, Y. 1999. Effect of lecithin on in vitro and in vivo survival of in vitro produced bovine blastocysts after cryopreservation. Theriogenology 52: 1193-1202.

12. Iwasaki, S. and Nakahara, T. 1990. Cell number and incidence of chromosomal anomalies in bovine blastocysts fertilized in vitro followed by culture in vitro or in vivo in rabbit oviducts. Theriogenology 33: 669-675.

13. Jiang, H.S., Wang, W.L., Lu, K.H., Gordon, I. and Polge, C. 1991. Roles of different cell monolayers in the co-culture of IVF bovine embryos. Theriogenology 35: 216 (abstract).

14. Kaidi, S., Donnay, I., Van Langendonckt, F., Dessy F. and Massip, A. 1998. Comparison of two co-culture systems to assess the survival of in vitro produced bovine blastocysts after vitrification. Anim. Reprod. Sci. 52: 39-50.

15. Keefer, C.L., Stice, S.L., Paprocki, A.M. and Golueke, P. 1994. In vitro culture of IVM-IVF embryos: cooperative interaction among embryos and the role of growth factors. Theriogenology 41: $1323-1331$.

16. Khurana, N.K. and Niemann, H. 2000. Effects of cryopreservation on glucose metabolism and survival of bovine morulae and blastocysts derived in vitro or in vivo. Theriogenology 54: 313326.

17. Kim, J.H., Funahashi, H., Niwa, K. and Okuda, K. 1993. Glucose requirement at different developmental stages of in vitro fertilized bovine embryos cultured in semi-defined medium. Theriogenology 39: 875-886.

18. Konishi, M., Itakura, H. and Aoyagi, Y. 1994. Effect of glucose in CR1aa on the development into blastocyst of in vitro fertilized bovine oocytes co-cultured with cumulus cells. $J$. Reprod. Dev. 40: j59-j64 (in Japanese).

19. Leibo, S.P. and Loskutoff, N.M. 1993. Cryobiology of in vitroderived bovine embryos. Theriogenology 39: 81-94.

20. Lonergan, P., O'Kearney-Flynn, M. and Boland, M.P. 1999. Effect of protein supplementation and presence of an antioxidant on the development of bovine zygotes in synthetic oviduct fluid medium under high or low oxygen tension. Theriogenology 51: 1565-1576.

21. Lu, K. H., Gordon, I., Gallagher, M. and McGovern, H. 1987. Pregnancy established in cattle by transfer of embryos derived from in vitro fertilisation of oocytes matured in vitro. Vet. Rec. 121: $259-260$

22. Matsuyama, K., Miyakoshi, H. and Fukui, Y. 1993. Effect of glucose levels during the in vitro culture in synthetic oviduct fluid medium on in vitro development of bovine oocytes matured and fertilized in vitro. Theriogenology 40: 595-605.

23. Niwa, K. and Ohgoda, O. 1988. Synergistic effect of caffeine and heparin on in-vitro fertilization of cattle oocytes matured in culture. Theriogenology 30: 733-741.

24. Pollard, J.W. and Leibo, S.P. 1993. Comparative cryobiology of in vitro and in vivo derived bovine embryos. Theriogenology 39: 287 (abstract).

25. Pollard, J.W. and Leibo, S.P. 1994. Chilling sensitivity of mammalian embryos. Theriogenology 41: 101-106.

26. Pugh, P.A., Ankersmit A.E.L., McGowan, L.T. and Tervit, H.R. 1998. Cryopreservation of in vitro-produced bovine embryos: effects of protein type and concentration during freezing or liposomes during culture on post-thaw survival. Theriogenology 50: 495-506.

27. Rieger, D., Loskutoff, M. and Betteridge, K.J. 1992. Developmentally related changes in the metabolism of glucose and glutamine by cattle embryos produced and co-cultured in vitro. J. Reprod. Fertil. 95: 585-595.

28. Rizos, D., Ward, F., Boland, M.P. and Lonergan, P. 2001. Effect of culture system on the yield and quality of bovine blastocysts as assessed by survival after vitrification. Theriogenology 56: 1-16.

29. Rosenkrans, Jr. C.F. and First, N.L. 1991. Culture of bovine zygotes to the blastocyst stage: effects of amino acids and vitamins. Theriogenology 35: 266 (abstract).

30. Rosenkrans, Jr. C.F., Zeng, G.Q., Mcnamara, G.T., Schoff, P.K. and First, N.L. 1993. Development of bovine embryos in vitro as affected by energy substrates. Biol. Reprod. 49: 459462.

31. Saha, S., Rajamahendran, R., Boediono, A., Sumantri, C. and Suzuki, T. 1996. Viability of bovine blastocysts obtained after 7,8 or 9 days of culture in vitro following vitrification and onestep rehydration. Theriogenology 45: 331-343.

32. Saito, N., Imai, K. and Tomizawa, M. 1994. Effect of sugarsaddition on the survival of vitrified bovine blastocysts produced in vitro. Theriogenology 41: 1053-1060.

33. Shamsuddin, M., Larsson, B., Gustafsson, H. and RodriguezMartinez, H. 1994. A serum-free, cell-free culture system for development of bovine one-cell embryos up to blastocyst stage with improved viability. Theriogenology 41: 1033-1043.

34. Takahashi, Y. and First, N. 1992. In vitro development of bovine one-cell embryo: Influence of glucose, lactate, pyruvate, amino acid and vitamins. Theriogenology 37: 963-978.

35. Tarin, J.J. and Trounson, A.O. 1993. Effects of stimulation or inhibition of lipid peroxidation on freezing-thawing of mouse embryos. Biol. Reprod. 49: 1362-1368.

36. Voelkel, S.A., Hu, Y.X., Moore, K. and Bondioli, K.R. 1992. Freeze survival of bovine embryos produced by in vitro maturation, fertilization and culture of oocytes. Theriogenology 37: 317 (abstract) 